\title{
PERLINDUNGAN INDUSTRI DALAM NEGERI DARI PRAKTIK DUMPING
}

\author{
Dewa Gede Pradnya Yustiawan (1) \\ Fakultas Hukum Universitas Udayana, Denpasar, Bali
}

\begin{abstract}
Dumping in international trading is an unfair competition which is commonly adopted by the entrepreneurs, that is by selling their product abroad with lower price then in domestic, in attention to have more customer. The strategy of dumping which is done by the entrepreneur gives an effect of financial loss to the domestic industries that produce the similar product. The problems are how is the control of protection for the domestic industries that produce the similar product, what is the measurement in establishing the financial loss for the domestic industries from the practice of dumping, and what effort can be done by the domestic producer who are suffered a financial loss because of the practice of dumping. The result of this research show that the regulations of the domestic industrial protection from the practice of dumping are the regulation in GATT and WTO and national law regulation. The criteria for the measurement in stating the financial loss of the domestic industries which produce the similar product from the practice of dumping are the financial loss, the threat of a real financial loss wich will be faced by the domestic industries that produce the similar product and the obstruction of the development of the domestic industries. The effort to avoid the practice of dumping that can be done by them is to follow the government procedures which have been stated in the government regulation No. 34.
\end{abstract}

Keywords: International Trading, Protection Industries, Dumping

\section{Pendahuluan}

Hubungan perdagangan antar negara yang dikenal dengan perdagangan internasional mengalami perkembangan yang pesat dari waktu ke waktu. Dinamika perdagangan internasional diikuti dengan berbagai permasalahan yang kompleks sebagai konsekuensi dari suatu hubungan perdagangan yang wajar terjadi dalam dunia bisnis. Ciri khas perdagangan internasional adalah adanya hubungan dagang yang dilakukan antar lintas batas-batas negara yang dilakukan oleh para pelaku usaha dengan mengikuti suatu sistem tertentu dan spesifik. Jika berbicara tentang perdagangan internasional, hal itu tidak akan lepas dari eksistensi suatu sistem. Dalam perdagangan internasional, eksistensi suatu sistem merupakan patron yang membentuk dan mengarahkan kegiatan-kegiatan perdagangan ke dalam tujuan-tujuan tertentu yang diinginkan².

${ }^{1}$ Christhophorus Barutu, 2007, Sejarah Sistem Perdagangan Internasional (Dari Upaya Pembentukan Internasional Trade Organization, Eksistensi General 
Dalam upaya membangun hubungan perdagangan lintas negara yang tertib, perlu dibuat ketentuan-ketentuan yang berupa aturan-aturan hukum yang bersifat mengatur yang diterima sebagai suatu kesepakatan bersama yang bertujuan menjamin agar terciptanya suatu perdagangan yang fair. Aturan hukum yang dimaksud berfungsi sebagai acuan (guidance) yang berlaku secara umum yang harus ditaati dan diawasi dan diberlakukan secara tegas untuk mengeliminasi atau mengurangi penyimpangan-penyimpangan yang dapat terjadi dalam hubungan perdagangan internasional. Selain itu yang tak kalah pentingnya adalah adanya eksistensi lembaga/organisasi yang memiliki kekuatan hukum yang mampu mengatur segala masalah yang terkait dalam perdagangan internasional.

Keinginan lahirnya suatu organisasi perdagangan yang bersifat multilateral telah lama timbul untuk mengatur masalah-masalah yang berkaitan dengan perdagangan global yang melibatkan kepentingan negara-negara di dunia yang memiliki komitmen bersama mewujudkan perdagangan internasional yang fair dan adil. Untuk mewujudkan integrasi sistem perdagangan dunia, beberapa negara besar mencoba untuk membentuk organisasi perdagangan dunia yang berfungsi untuk mengatur dan mengawasi suatu sistem perdagangan dunia yang ideal, yang dimualai dari upaya pembentukan Internasional Trade Organization (ITO), General Agreement on Tariffs and Trade (GATT) 1947, sampai terbentuknya World Trade Organization (WTO). Upaya pembentukan organisasi perdagangan dunia ini mencerminkan adanya keinginan yang kuat untuk mewujudkan suatu sistem perdagangan yang fair.

Membajirnya barang impor ilegal telah membuat produsen domestik menjadi kurang bersemangat untuk berproduksi, dan karena alasan inilah yang menjadikan mereka berubah menjadi importir. Barang-barang ilegal tersebut masuk ke Indonesia bagaikan air hujan yang membanjiri pasar domestik dalam jumlah yang sangat besar. Para produsen domestik merasa terjepit dengan adanya perdagangan yang tidak adil (unfair Trade) kompetisi seperti ini, mereka merasa adanya ketidak adilan dan merasa

Agreement On Tariffs and Trade Sampai Berdirinya World Trade Organization), Jurnal Hukum Gloris Juris, Fakultas Hukum Universitas Katholik Atmajaya, Volume 7, Nomor 1, 1 Januari 2007, April, Jakarta,(Selanjutnya disebut Christhophorus Barutu 1), h.5. 
adanya perebutan pasar domestik oleh para importir ilegal ${ }^{2}$.

Walaupun semua negara anggota WTO telah sepakat untuk menciptakan perdagangan dunia yang bebas, dimana semua hambatan perdagangan baik berbentuk tarif maupun non tarif dihapuskan. Maka arus barang dapat masuk ke semua negara dengan bebas, persaingan dalam merebut pasar menjadi semakin ketat, kemungkinan praktek perdagangan yang tidak sehat seperti dumping, subsidi dan manipulasi dokumen dapat saja terjadi, walaupun anggota WTO diwajibkan untuk melakukan suatu perdagangan yang sehat (Fair Trade). Globalisasi perdagangan menuntut kesiapan setiap anggota untuk bersaing secara sehat dan terbuka ${ }^{3}$.

Pesatnya dinamika perkembangan perdagangan internasional menyisakan sejumlah permasalahan sebagai implikasi dari kegiatan perdagangan internasional itu sendiri. Permasalahan-permasalahan tersebut dapat mengkristal dan menjadi hambatan (barrier) yang dapat mendorong terjadinya degradasi hubungan yang harmonis dalam hubungan perdagangan internasional. Dalam hubungan perdagangan internasional antarnegara, komitmen dalam mewujudkan perdagangan yang jujur dan fair merupakan tuntutan sangat penting yang tidak boleh diabaikan. Masalah-masalah terbesar yang mudah diidentifikasi dan yang paling sering terjadi adalah justru terkait dengan pelanggaran prinsip kejujuran dan fair yang mengakibatkan terjadinya praktik dagang yang tidak sehat (Unfair Trade Practices) dalam melaksanakan aktifitas perdagangan internasional ${ }^{4}$.

Ada banyak praktik perdagangan yang tidak sehat yang terjadi dalam hubungan perdagangan internasional dan yang paling banyak disorot adalah masalah dumping. Praktik dumping telah lama ditempatkan sebagai salah satu praktik dagang yang curang yang terjadi dalam konteks perdagangan internasional yang menimbulkan kerugian dan dapat

2 Direktorat Impor Ditjen Perdagangan Luar Negeri, 2003, Sosialisasi Mal Praktek/ Unfair Trade, Dinas Perindustrian dan Perdagangan, Provinsi Daerah Istimewa Yogyakarta, 29 Juli 2003, h.1.

${ }^{3}$ lbid.

${ }^{4}$ Christhophorus Barutu, 2007, Antidumping dalam General Agreement on Tariff and Trade (GATT) dan pengaruhnya terhadap peraturan Antidumping Indonesia, Mimbar Hukum, Jurnal Berkala Fakultas Hukum Universitas Gadjah Mada, Volume 19, Nomor 1, Februari 2007, Yogyakarta, (Selanjutnya disebut Christhophorus Barutu 2), h.53. 
memukul dunia usaha suatu negara tempat praktik dumping itu terjadi. Dengan menjual suatu jenis barang produksi ekspor dengan harga lebih rendah dari harga pasar dalam negeri, (negara pengimpor) mengakibatkan matinya pasar barang sejenis dalam negeri. Hal ini membuat barangbarang sejenis tersebut tidak lagi dapat bersaing secara kompetitif dan fair akibat perbedaan harga yang sangat drastis. Namun, dibalik itu semua hanya praktik dumping yang menimbulkan kerugian yang dapat dikategorikan sebagai unfair trade practices.

Bagi pelaku usaha yang melakukan ekspor yang terkena tuduhan dumping dapat berakibat berkurangnya ekspor, berkurangnya omzet penjualan, berkurangnya keuntungan yang didapat, wajib menanggapi serta memberikan informasi dan data-data yang diperlukan dalam penyelesaian sengketa dumping melalui World Trade Organization (WTO). Kemerosotan pendapatan, lebih jauh dapat mengakibatkan penurunan daya bayar perusahaan terhadap ongkos tenaga kerja, penurunan pembiayaan perusahaan, akhirnya penurunan daya produksi dan daya ekspor 5 .

\section{Pengertian umum tentang Dumping.}

Menurut Kamus Lengkap Perdagangan Internasional, dumping adalah penjualan suatu komuditi di suatu pasar luar negeri pada tingkat harga yang lebih rendah dari nilai yang wajar, biasanya dianggap sebagai tingkat harga yang lebih rendah dari pada tingkat harga di pasar domestiknya, atau negara ketiga, sedangkan menurut Kamus Hukum Ekonomi, dumping adalah praktik dagang yang dilakukan eksportir dengan menjual komuditi di pasaran internasional dengan harga kurang dari nilai yang wajar, atau lebih rendah dari pada harga barang tersebut di negerinya sendiri, atau dari pada harga jual kepada negara lain, pada umumnya, praktik ini dinilai tidak adil karena dapat merusak pasar dan merugikan produsen pesaing di negara pengimpor. ${ }^{6}$

Praktik dumping merupakan tindakan yang jelas-jelas dapat menimbulkan kerugian yang sangat serius terhadap perekonomian setiap negara yang mana setiap negara memerlukan perlindungan (protection)

5 Ida Bagus Wyasa Putra, 1997, Aspek-Aspek Hukum Perdata Internasional Dalam Transaksi Bisnis Internasional, Refika Adiatma, Bandung, h. 14.

6 Elips, 1997, Kamus Hukum Ekonomi, Jakarta, h. 105. 
yang memadai, sehingga lahirlah suatu instrument kebijaksanaan perdagangan yang dikenal dengan istilah antidumping. Dumping adalah suatu praktik penjualan barang di suatu pasaran ekspor dengan lebih rendah dari harga penjualan di pasar domestik, atau di bawah biaya produksi ${ }^{7}$. Kebijaksanaan anti dumping merupakan ketentuan-ketentuan yang menyoroti praktik dumping dan penjatuhan sanksi/hukuman terhadap pelaku praktik dumping dalam konteks perdagangan internasional.

Selain strategi persaingan harga, dikenal pula strategi persaingan bukan harga (non price competition) persaingan bukan harga ini dapat ditempuh dengan advertasi, kualitas, atau atribut lainnya seperti kemasan, warna, aroma, dan lain-lain. Dampak persaingan yang tidak jujur (unfair competition) dapat merugikan berbagai pihak / negara dalam perdagangan internasional. Oleh karena itu perlu adanya upaya untuk mengembangkan persaingan yang jujur dalam perdagangan internasional. Untuk mencapai hal tersebut maka munculah GATT (General Agrement on Tariff and Trade) GATT merupakan suatu persetujuan multilateral yang menentukan peraturan perdagangan internasional dengan tujuan untuk menciptakan perdagangan internasional yang bebas, terbuka dan kompetitif. Anggota GATT terdiri dari negara-negara yang ikut menandatangani dan menerapkan peraturan-peraturan yang telah ditandatangani (contracting parties).

Prinsip utama GATT adalah tidak ada diskriminasi (non discrimination) yang tercantum dalam klausa Most Favoured Nation (MFN). Prinsip ini mengharuskan setiap negara penandatangan persetujuan peraturan GATT memberikan perlakuan yang sama dalam kebijakan perdagangan internasional kepada negara penandatangan lain. Kelonggaran tarif yang diberikan kepada suatu negara atas dasar perjanjian bilateral, haruslah diberikan juga kepada negara penandatangan lain tanpa adanya perjanjian terlebih dahulu. Apabila terjadi perselisihan di antara negara penandatangan, GATT merupakan forum untuk konsultasi dalam penyelesaian sengketa (dispute settlement) dan juga mengawasi pelaksanaan peraturan-peraturan yang telah ditandatangani.

7 Direktorat Jendral Perdagangan Luar Negeri Departemen Perdagangan Republik Indonesia, 1992, Anti Dumping Code Latar Belakang Penafsiran dan Tinjauan atas Sejumlah Tuduhan Terhadap Indonesia, Proyek Pengembangan Perdagangan Luar Negeri pusat, Departement Perdagangan Republik Indonesia , Jakarta, h. 1 
Indonesia merupakan salah satu negara anggota organisasi perdagangan dunia (The World Trade Organization/WTO), karena telah meratifikasi Agreement Establishing the World Trade Organization sebagaimana diwujudkan dalam UU No. 7 tahun 1994. Sebagai negara anggota WTO, Indonesia harus mematuhi peraturan peraturan organisasi perdganan dunia tersebut. Keanggotaan tersebut membawa konsekuensi dikenakannya persetujuan-persetujuan yang ada dalam WTO. Salah satu persetujuan dalam WTO adalah persetujuan tentang pelaksanaan pasal IV dari persetujuan umum tentang tarif dan perdagangan 1994. Isi persetujuan tersebut berkenaan dengan dumping dan anti dumping.

Seiring dengan semakin liberalnya pasar global, praktik dagang yang tidak sehat semakin marak dan setiap negara mulai sadar dan merasa perlu untuk memberi perlindungan terhadap industri dalam negeri dan perdagangan dalam negerinya. Praktik perdagangan yang tidak sehat, termasuk praktik dumping dan atau subsidi yang dilakukan negara eksportir mengakibatkan kerugian (injury) bagi dunia usaha dan industri dalam negeri barang sejenis di negara pengimpor. Guna melindungi industri dalam negeri dari serbuan tuduhan praktik dumping, maka dibentuklah Komite Anti Dumping Indonesia (selanjutnya disingkat dengan KADI).

Berdasarkan uraian yang telah dijabarkan di atas, maka bisa ditarik permasalahan yaitu :

1. Bagaimanakah bentuk pengaturan perlindungan terhadap industri dalam negeri yang memproduksi barang sejenis dari praktik dumping.

2. Bagaimanakah cara penentuan kerugian (Injury) bagi industri dalam negeri yang memproduksi barang sejenis.

3. Upaya apakah yang dapat dilakukan oleh produsen dalam negeri yang memproduksi barang sejenis yang dirugikan akibat terjadinya praktik dumping.

\section{Pembahasan}

\subsection{Bentuk Pengaturan Perlindungan Terhadap Industri Dalam Negeri} Yang Memproduksi Barang Sejenis Dari Praktik Dumping.

Mengenai Anti-dumping dapat dilihat pengaturannya dalam GATTWTO dan pengaturan dalam hukum nasional. 


\section{a). Pengaturan Anti- Dumping Dalam GATT-WTO.}

Negara negara GATT pada saat berlakunya Persetujuan Pembentukan WTO menjadi "Original Members" WTO sepanjang sudah memenuhi persyaratan mengenai komitmen dan konsesi. Negara yang menjdi anggota WTO tentu saja wajib menerima Persetujuan Pembentukan WTO dan persetujuan persetujuan yang menjadi lampirannya, yang dalam hal ini adalah GATT, GATS ( General Agreement on Trade in Servises), dan TRIPs (Agreement on Trade Related of Intellectual Property Rights), atau secara keseluruhan disebutkan persetujuan perdagangan multilateral (Multilateral trade agreements).Indonesia adalah salah satu anggota "Original Members" dari WTO Cerminan dari diterimanya hasil hasil Putara Uruguay oleh Bangsa Indonesia adalah pengesahan keikutsertaan Indonesia dalam WTO dengan dikeluarkannya Undang-undang No. 7 tahun 1994 pada tanggal 2 Nopember 1994..Sudah jelas bahwa keikutsertaan Indonesia dalam WTO dan pelaksanaan berbagai komitmen yang disampaikan tidaklah terlepas dari rangkaian kebijaksanaan disektor perdagangan khususnya perdagangan luar negeri. ${ }^{8}$

Dalam Perdagangan luar negeri atau perdagangan internasional pengusaha untuk dapat merebut konsumen sebanyak mungkin, sering menempuh strategi persaingan harga (price competition), yaitu dengan menekan harga serendah mungkin untuk barang sejenis dengan perusahaan lainnya. Perbuatan tersebut dipandang sebagai perbuatan curang, karena melakukan suatu perbuatan dalam bentuk persaingan yang tidak jujur (unfair competition). Dalam perdagangan Internasional perbuatan curang tersebut dikenal sebagai praktik dumping, yaitu merupakan praktik dagang yang tidak fair, karena bagi negara pengimpor, praktik dumping akan menimbulkan kerugian bagi dunia usaha atau industri barang sejenis dalam negeri, dengan terjadinya banjir barang barang dari pengekspor yang harganya jauh lebih murah dari pada harga barang dalam negeri. Hal tersebut akan mengakibatkan barang sejenis kalah saing, sehingga akan mematikan pasar barang sejenis dalam negeri, dan pada akhirnya adalah industri barang sejenis dalam negeri menjadi bangkrut.

Untuk melindungi industri dalam negeri dari praktik dumping, maka

8 .B.M. Kuntjoro Jakti,et.al.,1997/1998,Pengkajian Hukum Tentang Masalah Penyelesaian Sengketa Dagang Dalam WTO,BPHN,Jakarta, h.7-8 
dikeluarkan peraturan antidumping yang merupakan salah satu perhatian khusus Indonesia terhadap hasil putaran Uruguay. Peraturan antidumping terdapat dalam Persetujuan Anti-Dumping GATT, yaitu pada article VI dari GATT 1994 yang terdiri dari 7 (tujuh) ayat.

Persetujuan atas implementasi Article VI GATT dikenal sebagai Anti Dumping Agreement (ADA) di mana menyediakan perluasan lebih lanjut atas prinsip prinsip dasar dalam Article VI GATT itu sendiri, memerintahkan investigasi,ketentuan, dan aplikasi bea antidumping. Dalam article VI GATT 1994, para anggota WTO dapat membebankan/mengenakan antidumping measures jika setelah investigasi sesuai dengan persetujuan, suatu ketentuan dibuat, yaitu :

a. bahwa dumping sedang terjadi,

b. bahwa industri domestik memproduksi produk yang sama (like product) di negara pengimpor mendapatkan/memperoleh material injury, dan

c. bahwa ada suatu hubungan sebab akibat (causal link) antara keduanya.

Ketiga unsur di atas ditegaskan dalam Article 5.2 Agreement on Implementation of Article VI of The General Agreement on Tarifs and Trade 1994(Anti-Dumping Agreement/ADA)

\section{b). Pengaturan Anti-Dumping Dalam Hukum Nasional.}

Pengaturan anti dumping dalam hukum nasional Indonesia sebagai tindak lanjut dari ratifikasi Pesetujuan Pembentukan WTO melalui Undangundang No.7 tahun 1994 ternyata sampai saat ini belum ada pengaturannya secara khusus dalam satu peraturan yang berbentuk undang-undang. Pengaturan anti dumping dalam hukum nasional Indonesia tersebar dalam Peraturan Perundang-undangan, Peraturan Pemerintah, dan produk produk hukum lainnya yang terkait seperti Keputusan Menteri Perindustrian dan Perdagangan, dan Surat Edaran Dirjen Bea dan Cukai sebagai berikut.

1. Undang-undang Nomor 7 tahun 1994 tentang pengesahan (ratifikasi) Agreement Establishing the World Trade Organization. Dengan adanya pengesahan tersebut maka persetujuan itu yang berisi 28 ketentuan telah sah menjadi bagian dari peraturan nasional, dan sekaligus meratifikasi pula Anti dumping Code tahun 
1994 yang merupakan salah satu dari Multilateral Trade Agreement.

2. Undang-undang Nomor 10 tahun 1995 tentang Kepabeanan yang telah diubah dengan dikeluarkannya Undang-undang Nomor 17 tahun 2006 tentang Perubahan Atas Undang-undang Nomor 10 tahun 1995 tentang Kepabeanan.

3. Peraturan Pemerintah Nomor 34 tahun 1996 tentang Bea Masuk Anti dumping dan Bea Masuk Imbalan.

4. Keputusan Menteri Perindustrian dan Prdagangan Nomor 261/MPP/Kep/9/1996 tentang Tata Cara dan Peryaratan Permohonan Penyelidikan Atas Barang Dumping dan atau Barang Mengandung Subsidi, sebagaimana telah diubah dengan Keputusan Menteri Perindustrian dan Perdagangan Nomor 216/MPP/Kep/7/2001 sebagai ketentuan hukum acara(formal), dan ketentuan pembentukan Komite Anti Dumping Indonesia (KADI) berdasarkan Keputusan Menteri Perindustrian dan Perdagangan Nomor 427/MPP/Kep/10/2000 tentang Komite Anti Dumping indonesia, dan Keputusan Menteri Perindustrian dan Perdagangan Nomor 428 /MPP/Kep/10/2000 tentang Penunjukan dan Pengangkatan Anggota Komite Andi Dumping Indonesia serta Struktur Kepegawaian Komite Anti Dumping Indonesia berdasarkan Keputusan Ketua Komite Anti Dumping Indonesia Nomor 346/KADI/Kep/10/2000 tentang Penunjukan dan Pengangkatan Kepala Bidang dan Anggota di Lingkungan Komite Anti Dumping Indonesia.

5. Surat Edaran Dirjen Bea dan Cukai Nomor SE-19/BC/1997 tentang Petunjuk Pelaksanaan Pemungutan Bea Masuk Anti Dumping/Sementara.

Peraturan peraturan tersebut dapat digunakan dalam penanganan kasus kasus dumping di Indonesia, terutama untuk pelaksanaan persyaratan dan tata cara pengenaan bea masuk anti-dumping dan bea masuk imbalan bagi produk produk dari luar negeri yang masuk ke dalam negeri sebelum adanya undang undang nasional yang secara khusus mengatur anti-dumping. Indonesia dengan meratifikasi Agreement Establishing the World Trade Organization dengan dikeluarkannya Undang 
undang No.7 tahun1994 tanggal 2 Nopember 1994, maka Indonesia harus mengimplementasikan persetujuan yang telah sah menjadi bagian dari peraturan nasional.

\subsection{Cara penentuan kerugian (Injury) bagi industri dalam negeri yang memproduksi barang sejenis.}

Dalam pengertian ini kerugian yang dimaksud adalah kerugian yang akan timbul disebabkan karena terhalangnya pengembangan industri dalam negeri barang sejenis yang diakibatkan oleh adanya barang dumping. Selain adanya hambatan pengembangan industri dalam negeri juga hambatan lahirnya industri baru. Batasan kerugian yang diatur oleh ketentuan tersebut diatas sangat luas, mengakibatkan pengertian tersebut menjadi bias. Luasnya pengertian kerugian tersebut dapat mengakibatkan perangkat hukum anti dumping dijadikan instrument oleh pengusaha (produsen) untuk melindungi kepentingan kelangsungan usahanya. ${ }^{9}$

GATT menetapkan suatu kriteria umum mengenai kerugian akibat prkatik dumping, yaitu dumpig yang dapat menimbulkan kerugian material, baik terhadap industri yang sudah berdiri maupun telah menimbulkan hambatan pada pendirian industri domestik. Disebut terjadi kerugian (injury) apabila faktor-faktor ekonomi dari perusahaan negara pengimport mengalami kerugian secara material, misalnya penurunan penjualan, keuntungan, pangsa pasar, produktifitas, return on investment, atau utilisasi kapasitas. Faktor-faktor yang mempengaruhi dalam negeri misanya margin dumping, pengaruh negative pada cash flow (arus kas), persediaan, tenaga kerja, upah, pertumbuhan, kemampuan meningkatkan modal, investasi. ${ }^{10}$

Untuk mengetahui apakah suatu negara telah melakukan praktik dumping yang menimbulkan kerugian material atau tidak, Article3.1. dari Antidumping Code 1994 menyatakan sebagai berikut.

"A determination on injury for purpose of article VI of GATT 1994 shall be based on positive evidence and involve and obyektive examination of both (a) the volume of the dumped import and the effect $f$ the dumped imports on price in the domestic market for like products, and (b) the consequent impact of these import on domestic producers of such product"

9 Yulianto syahyu, 2004, Hukum Anti Dumping di Indonesia, Ghali, Indonesia, Jakarta, h 106-107.

${ }^{10}$ Christhophorus Barutu 3, Op.cit. h. 45. 
Dari ketentuan tersebut dapat diartikan kerugian ditentukan berdasarkan adanya bukti-bukti positive dan hasil penyelidikan yang obyekstif tehadap :

a). Peningkatan volume import dari produk yang telah dijual dengan harga dumping, dan.

b). Pengaruh pratik dumping terhadap harga pasar dari produk barang sejenis yang diproduksi produsen domestik ${ }^{11}$

Menurut Yulianto Syahyu batasan kerugian yang timbul akibat praktik dumping cukup dibatasi sampai kerugian nyata (material Injury), dimana industri dalam negeri yang memproduksi barang sejenis telah benar-benar mengalami kerugian sebagai akibat adanya barang dumping. ${ }^{12}$

Dalam penyelidikan anti-dumping, penentuan ada tidaknya kerugian dalam hal adanya dumping sangat penting, karena jika ternyata dumping dapat dibuktikan tetapi tidak ada kerugian, maka bea masuk anti-dumping tidak dapat diterapkan. ${ }^{13}$

Ada variabel sebab akibat yang diajukan oleh GATT untuk melarang tindakan dumping, yaitu dumping yang dilakukan oleh suatu negara yang Less than fair value atau (LTFV) dianggap dapat menyebabkan kerugian material (Material injury) terhadap industri dalam negara importir. Jadi tindakan itu :

1). Harus ada tindakan dumping yang Less than fair value atau (LTFV).

2). Harus ada kerugian material di negara importir.

3). Adanya causal Link antara harga dumping dengan kerugian yang terjadi. ${ }^{14}$

\subsection{Upaya yang dapat dilakukan oleh produsen dalam negeri yang} memproduksi barang sejenis yang dirugikan akibat terjadinya praktik dumping.

Dalam upaya untuk melindungi industri dalam negeri dari praktik dumping, karena Indonesia telah meratifikasi Agreement Establishing the

\footnotetext{
${ }^{11}$ Yulianto syahyu, Loc.cit

12 Yulianto syahyu, op.cit, h.107

13 Yulianto syahyu, op.cit, h. 77

${ }^{14}$ Sukarmi, Loc.cit.
} 
World Trade Organization, maka ada suatu perjanjian atau kontrak di antara negara negara yang meratifikasi untuk menerapkan persetujuan persetujuan yang telah disepakati itu. Hal ini dapat didasarkan pada teori kontrak sebagaimana dikemukakan oleh Rudolf Von Jehring, bahwa kontrak tidak lain dari pada janji (promise). Janji menurut Jehring memiliki kekuatan hukum, yaitu kekuatan hukum yang tidak berasal dari hal hal di luar dari janji para pihak, tetapi dari fungsi praktis(practical function) dari janji itu sendiri5 Tanpa adanya kekuatan mengikat dari janji itu, maka perjanjian itu menjadi tidak ada artinya dalam hubungan bisnis. Konsekuensinya, hubungan bisnis hanya akan berlangsung di antara pihak yang sudah benar-benar dikenal satu sama lainnya.

Pihak-pihak yang dapat mengajukan kerugian akibat adanya praktik dumping tersebut adalah :

a) Produsen dalam negeri Indonesia yang mengalami kerugian serius atau ancaman kerugian serius akibat lonjakan impor barang sejenis, barang terselidik dan atau barang yang secara langsung bersaing.

b) Asosiasi produsen barang sejenis, barang terselidik dan atau barang yang secara langsung bersaing.

c) Organisasi buruh yang mewakili kepentingan industri dalam negeri barang sejenis barang terselidik dan atau barang yang secara langsung bersaing.

Dengan adanya keputusan Menteri Perindustrian dan Perdagangn tersebut, maka Komite Anti Dumping Indonesia (KADI) merupakan satu-satunya instrumen yang legal yang dapat dipakai untuk melindungi industri dalam negeri dari persaingan barang impor yang tidak fair yang masuk ke Indonesia dengan harga dumping atau mengandung subsidi. Dengan dibentuknya Komite Anti Dumping Indonesia (KADI) itu maka produsen ekportir Idonesia yang dituduh melakukan praktik perdagangan yang tidak sehat di negara tujuan ekspor akan mendapatkan perlindungan maupun pembelaan dari Komite Anti Dumping Indonesia (KADI) tersebut.

Komite Anti Dumping Indonesia (KADI) dibentuk untuk menangani

15 Rudolf Von Jehring, 1959, Law as a Mens to an End, dalam Clarence Morris ed, the Great Legal Philosophers Selected Reasing in Jurisprudence, University of Pennsylvania Press, Philadelphia, h.406 
permasalahan yang berkaitan dengan upaya penanggulangan dumping dan barang mengandung subsidi. Dengan demikian Komite Anti Dumping Indonesia (KADI) selain sebagai lembaga teknis administrasi, juga sebagai lembaga penegak hukum terutama yang berkaitan dengan bidang anti dumping. upaya yang dapat dilakukan oleh produsen dalam negeri yang memproduksi barang sejenis yang mengalami kerugian atau ancaman kerugian karena adanya barang impor yang dijual secara dumping atau mengandung subsidi dapat mengajukan permohonan perlindungan kepada Komite Anti Dumping Indonesia (KADI) baik secara perorangan atau kelompok. Atas dasar permohonan tersebut, Komite Anti Dumping Indonesia (KADI) akan melakukan penyelidikan untuk membuktikan kebenaran adanya dumping atau subsidi tersebut, dan terjadinya kerugian atau ancaman kerugian yang disebabkan oleh barang impor tersebut. Jika terbukti akan ditetapkan besarnya perlindungan yang dapat diberikan dengan menaikan bea masuk impor.

Kedua instrumen ini, baik anti dumping maupun subsidi digolongkan sebagai intrumen untuk mencegah terjadinya perdagangan yang curang yang dapat menimbulkan kerugian yang serius terhadap industri dalam negeri di negara pengimpor. Dalam WTO keberadaan ketentuan antidumping diatur dalam Anti dumping Agreement (ADA). Dalam persetujuan ini, diatur cara dan mekanisme untuk melakukan investigasi dan jangka waktu pengenaan antidumping yang bertujuan untuk mengatur agar negara-negara pengguna instrumen ini untuk melakukan praktik penyalahgunaan instrumen ini untuk melakukan prokteksi yang berlebihan dan tidak perlu yang dapat menimbulkan ketidakpastiaan dalam perdagangan internasional.

Pemerintah diminta lebih serius dalam melindungi industri dalam negeri, terutama dalam menggunakan berbagai instrumen kebijakan impor, untuk memberikan proteksi bagi produksi dalam negeri. Sekalipun indonesia terikat dengan WTO dan mendukung perdagangan bebas, bukan berarti menjadi halangan untuk melakukan proteksi. Masih banyak cara yang bisa dilakukan tanpa harus melanggar perjanjian WTO. Kehadiran Undang-undang anti dumping sangat di harapkan dalam menghadapi perdagangan bebas walaupun selama ini sejak tahun 1996 Indonesia telah mempunyai ketentuan yang mengatur tentang bea masuk anti dumpig dan 
bea masuk imbalan (Peraturan Pemerintah No. 34 tahun 1996). Namun perlu diketahui bahwa Peraturan Pemerintah No. 34 Tahun 1996 merupakan salah satu peraturan pelaksana dari Undang-undang No. 10 tahun 1995 tentang Kepabeanan, sedangkan masalah dumping merupakan masalah yang kompleks, yaitu tidak hanya berkaitan dengan masalah kepabeanan tetapi masih banyak keterkaitan dengan masalah lain, misalnya masalah mutu barang, politik, keuangan, kebijakan, dan sebagainya.

Dalam menerapkan ketentuan anti dumping berdasarkan GATTWTO, Peraturan Pemerintah No. 34 tahun 1996 kurang mengakomodasi semua ketentuan GATT-WTO tentang anti dumping. Prosedur penyelesaian sengketa GATT pada dasarnya mempunyai tiga tujuan, yaitu realisasi dari tujuan GATT, perlindungan keuntungan yang berasal dari perjanjian, dan untuk penyelesaian sengketa itu sendiri ${ }^{16}$, sehingga masih adanya kekaburan yang perlu penafsiran-penafsiran terutama dalam penentuan harga normal, kerugian (Injury), dan Causal Link sehingga tidak memberikan kepastian hukum dan perlindungan kepada produsen dalam negeri dimana dalam kasus tindakan dumping sering kali merugikan produsen dalam negeri yang memproduksi barang sejenis.

Pengaturan anti dumping dalam hukum nasional Indonesia sebagai tindak lanjut dari ratifikasi Pesetujuan Pembentukan WTO melalui Undangundang No.7 tahun 1994 ternyata sampai saat ini belum ada pengaturannya secara khusus dalam satu peraturan yang berbentuk undang-undang. Pengaturan anti dumping dalam hukum nasional Indonesia tersebar dalam Peraturan Perundang-undangan, Peraturan Pemerintah, dan produk produk hukum lainnya yang terkait seperti Keputusan Menteri Perindustrian dan Perdagangan, dan Surat Edaran Dirjen Bea dan Cukai.

${ }^{16}$ Faisal Salam, 2007, Penyelesaian Sengketa Bisnis Secara Nasional dan Internasional, Mandar Maju, Bandung, h. 442. 


\section{Lingkup Tindakan Pengamanan Perdagangan indonesia}

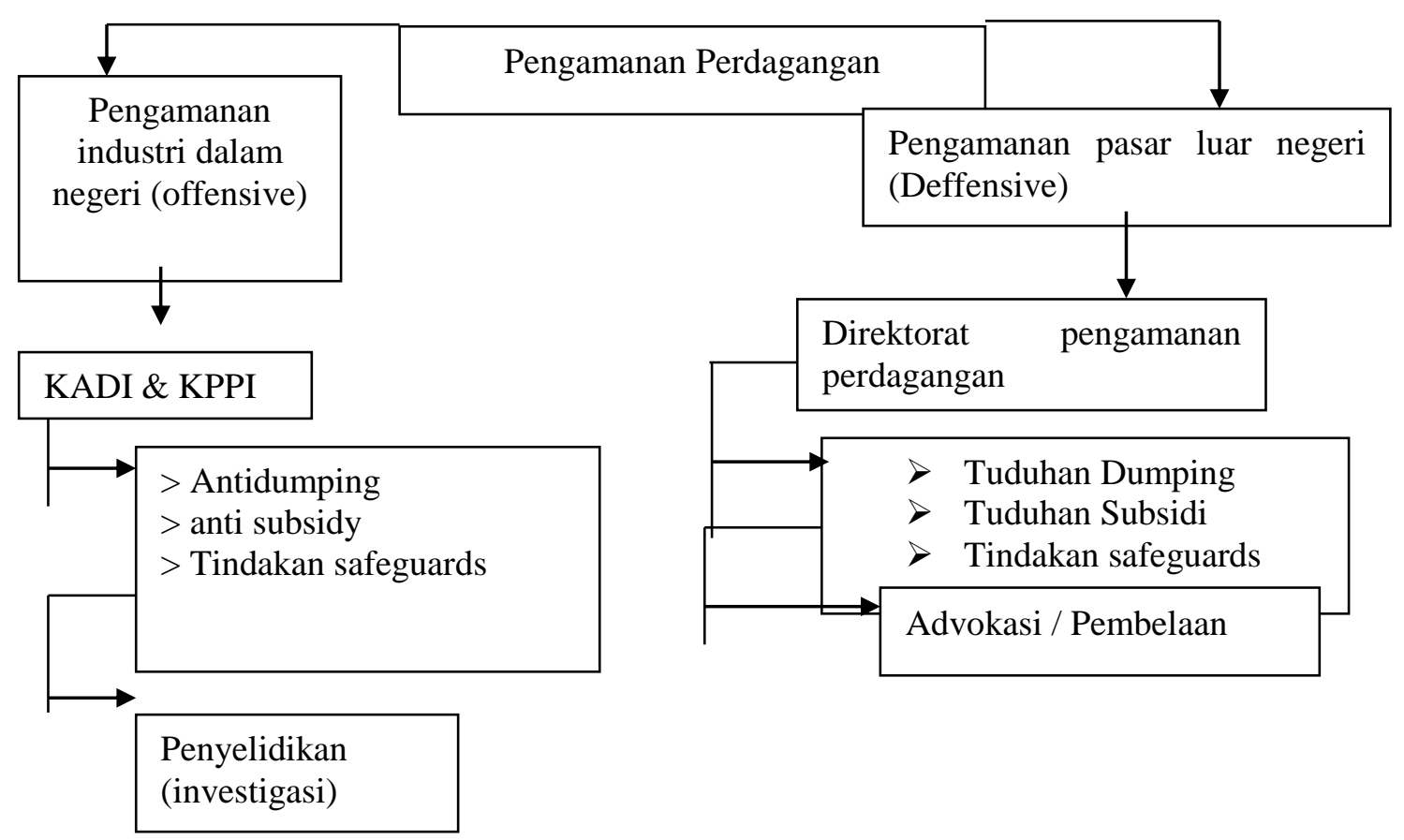

\section{Sumber : $\quad$ Komite Anti Dumping Indonesia (KADI).}

\section{Penutup.}

Berdasarkan pembahasan yang telah diuraikan diatas, maka bisa ditarik suatu kesimpulan sebagai berikut :

1. Produk-produk hukum yang terkait dengan upaya perlindungan industri dalam negeri dari praktik dumping adalah peraturan pemerintah sebagai hukum materialnya, yang kemudian diikuti dengan dikeluarkannya keputusan Menteri Perindustrian dan Perdagangan sebagai hukum formalnya. Disamping keputusan Menteri Perindustrian dan Perdagangan, juga dikeluarkan keputusan Presiden tentang tindakan pengamanan industri dalam negeri akibat lonjakan import. Walaupun peraturan-peraturan tersebut bertujuan untuk melindungi industri dalam negeri yang memproduksi barang-barang sejenis dari praktik dumping, tetapi sampai saat ini secara realita belum ada peraturan khusus dalam bentuk peraturan perundang-undangan yang mengatur anti dumping sebagai hukum nasional.

2. Cara yang digunakan dalam menentukan adanya kerugian (injury) bagi industri dalam negeri yang memproduksi barang sejenis adalah 
berdasarkan pada keadaan atau faktor-faktor ekonomi dari perusahaan negara pengimport tersebut, misalnya penurunan penjualan, keuntungan , pangsa pasar, produktivitas, return of investment, atau utilitasi kapasitas, sedangkan factor-faktor yang mempengaruhi dalam negeri misalnya margin dumping, pengaruh negative pada cash flow (arus kas), persediaan, tenaga kerja, upah, pertumbuhan, kemapuan meningkatkan modal, atau investasi. Factor-faktor tersebut yang digunakan untuk menentukan adanya kerugian (injury) bagi industri dalam negeri yang memproduksi barang sejenis.

3. Upaya yang dapat dilakukan oleh produsen dalam negeri yang memproduksi barang sejenis yang mengalami kerugian atau ancaman kerugian karena adanya barang import yang dijual secara dumping atau mengandung subsidi yaitu dapat mengajukan permohonan perlindungan kepada Komite Anti Dumping Indonesia (KADI) baik secara perorangan atau kelompok. Atas dasar permohonan tersebut, KADI akan melakukan penyelidikan untuk membuktikan kebenaran adanya dumping atau subsidi tersebut, dan terjadinya kerugian atau ancaman kerugian yang disebabkan oleh barang import tersebu. Jika terbukti akan ditetapkan besarnya perlindungan yang dapat diberikan dengan manaikan bea masuk import.

\section{DAFTAR PUSTAKA}

B.M. Kuntjoro Jakti,et.al.,1997/1998,Pengkajian Hukum Tentang Masalah Penyelesaian Sengketa Dagang Dalam WTO,BPHN,Jakarta, h.7-8 Christhophorus Barutu, 2007, Sejarah Sistem Perdagangan Internasional (Dari Upaya Pembentukan Internasional Trade Organization, Eksistensi General Agreement On Tariffs and Trade Sampai Berdirinya World

Christhophorus Barutu, 2007, Antidumping dalam General Agreement on

Tariff and Trade (GATT) dan pengaruhnya terhadap peraturan

Antidumping Indonesia, Mimbar Hukum, Jurnal Berkala Fakultas

Hukum Universitas Gadjah Mada, Volume 19, Nomor 1, Februari 2007, Yogyakarta, (Selanjutnya disebut Christhophorus Barutu 2),h.53. 
Direktorat Jendral Perdagangan Luar Negeri Departemen Perdagangan

Republik Indonesia, 1992, Anti Dumping Code Latar Belakang

Penafsiran dan Tinjauan atas Sejumlah Tuduhan Terhadap Indonesia,

Proyek Pengembangan Perdagangan Luar Negeri pusat, Departement

Perdagangan Republik Indonesia , Jakarta, h. 1

Direktorat Impor Ditjen Perdagangan Luar Negeri, 2003, Sosialisasi Mal

Praktek/ Unfair Trade, Dinas Perindustrian dan Perdagangan,

Provinsi Daerah Istimewa Yogyakarta, 29 Juli 2003, h.1.

Elips, 1997, Kamus Hukum Ekonomi, Jakarta, h. 105.

Faisal Salam, 2007, Penyelesaian Sengketa Bisnis Secara Nasional dan Internasional, Mandar Maju, Bandung, h. 442.

Ida Bagus Wyasa Putra, 1997, Aspek-Aspek Hukum Perdata Internasional Dalam Transaksi Bisnis Internasional, Refika Adiatma, Bandung, h. 14.

Rudolf Von Jehring, 1959, Law as a Mens to an End, dalam Clarence

Morris ed, the Great Legal Philosophers Selected Reasing in Jurisprudence, University of Pennsylvania Press, Philadelphia, h.406

Yulianto syahyu, 2004, Hukum Anti Dumping di Indonesia, Ghali, Indonesia, Jakarta, h 106-107. 